\title{
Bacillus safensis sp. nov., isolated from spacecraft and assembly-facility surfaces
}

\author{
Correspondence \\ Kasthuri Venkateswaran \\ kjvenkat@jpl.nasa.gov
}

\author{
Masataka Satomi, ${ }^{1,2}$ Myron T. La Duc ${ }^{2}$ and Kasthuri Venkateswaran ${ }^{2}$ \\ ${ }^{1}$ National Research Institute of Fisheries Science, Fisheries Research Agency, Yokohama, \\ 236-8648, Japan \\ ${ }^{2}$ Biotechnology and Planetary Protection Group, Jet Propulsion Laboratory, California Institute \\ of Technology, Pasadena, CA 91109, USA
}

Spacecraft and associated clean-room assembly-facility surfaces harbour an extremely low biomass (La Duc et al., 2003; Venkateswaran et al., 2001), because of stringent maintenance. However, colonization by micro-organisms specifically adapted to such facility conditions, especially those yet to be cultured and/or characterized, is of major concern to those commissioning modern-day space-related experimentation. The search for extraterrestrial life will rely heavily on validated cleaning and bioreduction strategies to ensure that terrestrial microbial contamination does not compromise the scientific integrity of such missions. It is crucial both to minimize and eradicate such microbial contaminants and to identify and characterize the recurring,

\footnotetext{
Abbreviation: MALDI-TOF MS, matrix-assisted laser desorption/ionization time-of-flight mass spectrometry.

The GenBank/EMBL/DDBJ accession numbers for the $16 \mathrm{~S}$ rRNA and gyr $B$ gene sequences referred to in this communication are given in Table 1.

A dendrogram based on rep-PCR fingerprinting and details of DNADNA hybridization among Bacillus strains isolated from the JPL spacecraft assembly facility are available as supplementary material in IJSEM Online.
}

prevalent micro-organisms associated with the surfaces of spacecraft and associated environments.

Studies have repeatedly shown that extremely resilient, spore-forming members of the genus Bacillus are the most strongly represented micro-organisms in samples collected from spacecraft and facility surfaces (La Duc et al., 2003; Puleo et al., 1977). The extremely oligotrophic, lowhumidity, temperature-controlled conditions of spacecraftassembly facilities appear to select for micro-organisms able to withstand such unfavourable surroundings. During monitoring of the microbial diversity of spacecraftassociated environments over a period of 5 years (1999-2004), Bacillus pumilus was found to be the second most dominant species among the aerobic spore-forming bacteria (the predominant species being Bacillus licheniformis; La Duc et al., 2004a). Several of these B. pumilus isolates have exhibited elevated resistance to $\mathrm{H}_{2} \mathrm{O}_{2}$ (Venkateswaran et al., 2001; Kempf et al., 2005) and are thus considered as 'problematic' micro-organisms, since $\mathrm{H}_{2} \mathrm{O}_{2}$ is recommended for the bioreduction of spacecraft components.

In previous studies using MALDI-TOF MS (matrix-assisted laser desorption/ionization time-of-flight mass spectrometry) 
to assess similarities amongst isolates, two very distinct and consistent groups of B. pumilus were revealed (Dickinson et al., 2004). A detailed taxonomic characterization of this group of bacteria was deemed necessary to clarify the distribution of these species in spacecraft-assembly facilities. Here, we report the results of a study in which phenotypic characteristics and the results of phylogenetic analyses of 16S rRNA and gyrB gene sequences, repetitive element primer (rep)-PCR fingerprinting and DNA-DNA hybridizations for several novel isolates were compared.

The bacterial strains examined in this study are shown in Table 1. A total of 13 strains of this novel micro-organism were isolated from spacecraft and assembly-facility surfaces by standard swabbing procedures (Anonymous, 1980; La Duc et al., 2004b) at various times and locations. Comparative analyses were performed with these newly described strains, four B. pumilus strains isolated from spacecraftassembly facilities or International Space Station hardware and two strains purchased from the American Type Culture Collection (Manassas, VA, USA), including the B. pumilus type strain ATCC $7061^{\mathrm{T}}$. All strains were maintained in trypticase soy agar (TSA) stabs at room temperature for short-term analysis and in glycerol at $-80^{\circ} \mathrm{C}$ for long-term storage. Liquid cultures were grown in trypticase soy broth (TSB; Becton Dickinson) at $32^{\circ} \mathrm{C}$ with vigorous aerobic shaking for an appropriate period of time.
Cellular morphology and motility were examined by phasecontrast microscopy. Gram staining was performed using the modified Hucker method (Smibert \& Krieg, 1994). A nutrient sporulation medium rich in divalent cations was used to produce spores, as described previously (Schaeffer $e t$ al., 1965; Nicholson \& Setlow, 1990). The refractile nature of the spores was examined by using phase-contrast microscopy (Olympus BX-60). The optimum $\mathrm{NaCl}$ concentration for growth was determined in salt-free TSB supplemented with $0,5 \cdot 0,7 \cdot 5,10 \cdot 0,12 \cdot 5$ and $15 \cdot 0 \%(\mathrm{w} / \mathrm{v}) \mathrm{NaCl}$, and cultures were monitored for growth for 3 weeks with incubation at $32^{\circ} \mathrm{C}$. Optimum and limiting temperatures were determined by growing cells at $4,10,37,50$ and $55^{\circ} \mathrm{C}$ on TSA for 3 weeks. Routine biochemical tests were carried out using commercially available API kits [API 20NE, API 20E, API $50 \mathrm{CH}$ (assimilation), API $50 \mathrm{CH}$ (acid production) and API ZYM], which were utilized according to the instructions of the manufacturer (bioMérieux). Nutritional requirements for growth were assessed using Davis minimum medium (Becton Dickinson). Casein hydrolysis, starch hydrolysis and the production of lipase (hydrolysis of Tweens 20, 40 and 80) were tested as described by Smibert \& Krieg (1994). Whole-cell fatty acid methyl ester profiles for the novel isolates and reference strains were determined using the MIDI system (Sasser, 1990). The DNA G+C content was determined by using the HPLC method of Tamaoka \& Komagata (1984).

Table 1. Strains investigated in this study and their sources of isolation

JPL-SAF, Jet Propulsion Laboratory spacecraft-assembly facility; KSC, Kennedy Space Center.

\begin{tabular}{|c|c|c|c|}
\hline \multirow[t]{2}{*}{ Strain } & \multicolumn{2}{|c|}{ GenBank accession number } & \multirow[t]{2}{*}{ Source, location and year of isolation } \\
\hline & 16S rRNA gene & gyrB gene & \\
\hline FO- $36 b^{\mathrm{T}}\left(=\right.$ ATCC BAA- $1126^{\mathrm{T}}=$ NBRC $\left.100820^{\mathrm{T}}\right)$ & AF234854 & AY167867 & Clean-room air particulate, JPL-SAF, 1999 \\
\hline FO-33 & AF234851 & AY167868 & Clean-room air particulate, JPL-SAF, 1999 \\
\hline SAFN-001 $(=$ ATCC BAA-1128 = NBRC 100821) & AY167886 & AY167877 & Entrance floor, JPL-SAF, 2001 \\
\hline SAFN-036 & AY167881 & AY167873 & Clean-room floor, JPL-SAF, 2001 \\
\hline SAFN-037 & AY167880 & AY167872 & Clean-room floor, JPL-SAF, 2001 \\
\hline KL-052 (=ATCC BAA-1129=NBRC 100822) & AY030327 & AY167878 & Clean-room cabinet top, JPL-SAF, 2001 \\
\hline 51-3C (=ATCC BAA-1127= NBRC 100823) & AF526907 & - & Mars Odyssey spacecraft surface, 2002 \\
\hline $81-4 \mathrm{C}$ & AF526903 & - & Mars Odyssey assembly-facility floor, KSC, 2002 \\
\hline $82-2 \mathrm{C}$ & AF526902 & - & Mars Odyssey assembly-facility floor, KSC, 2002 \\
\hline \multicolumn{4}{|l|}{ Bacillus pumilus } \\
\hline ATCC $7061^{\mathrm{T}}$ & AY876289 & AY167869 & Reference strain \\
\hline ATCC 27142 & AY876287 & AY167870 & Reference strain \\
\hline SAFN-029 & AY167883 & AY167875 & Clean-room airlock, JPL-SAF, 2001 \\
\hline SAFN-034 & AY167882 & AY167874 & Clean-room airlock, JPL-SAF, 2001 \\
\hline SAFR-032 & AY167879 & AY167871 & Clean-room airlock, JPL-SAF, 2001 \\
\hline $0105342-2$ & AY876228 & - & International Space Station hardware, 2001 \\
\hline
\end{tabular}


The novel isolates were Gram-positive, spore-forming rods and were aerobic, motile and oxidase- and catalase-positive and so demonstrated several morphological and physiological characteristics typical of members of the genus Bacillus (Claus \& Berkeley, 1986); this indicated that all of these isolates belonged to this genus or related genera. The Biolog identification system indicated that the novel isolates were most similar to B. pumilus (Dickinson et al., 2004). Additionally, 174 phenotypic tests were performed to study the phenotype of the novel isolates. Two phenotypic characteristics, acid production from inositol and utilization of inositol, allowed the discrimination of the novel isolates from B. pumilus (Table 2). Additional phenotypic characteristics (production of acid phosphatase, Tween 80 hydrolysis, casein hydrolysis in litmus milk and utilization of raffinose) were also useful for separating these two bacterial groups, though responses to various substrates were variable among strains. Further details regarding physiological and phenotypic characteristics are discussed in the species description. The major fatty acids of the novel isolates were $\mathrm{C}_{15: 0}$ iso $(50 \cdot 4-56 \cdot 7 \%), \mathrm{C}_{15: 0}$ anteiso $(23 \cdot 3-$ $25 \cdot 2 \%), \mathrm{C}_{17: 0}$ iso $(4 \cdot 52-6 \cdot 93 \%)$ and $\mathrm{C}_{17: 0}$ anteiso $(3 \cdot 71-$ $4 \cdot 69 \%)$. All of the novel isolates and the five B. pumilus strains tested in this study had similar fatty acid methyl ester profiles. The DNA G $+\mathrm{C}$ contents of novel isolates FO$36 \mathrm{~b}^{\mathrm{T}}, \mathrm{KL052}$, SAFN001 and 51-3C were $41 \cdot 0,41 \cdot 0,41 \cdot 4$ and $41.2 \mathrm{~mol} \%$, respectively. The $\mathrm{G}+\mathrm{C}$ contents of $B$. pumilus strains ATCC $7061^{\mathrm{T}}$ and SAFR032 were $40 \cdot 2$ and $39.5 \mathrm{~mol} \%$, respectively.

For the phylogenetic and genetic analyses, genomic DNA was extracted using standard methods (Johnson, 1981; Sambrook et al., 1989) from strains cultured in TSB supplemented with $2 \%$ glycine. The $16 \mathrm{~S}$ rRNA and gyrB genes were PCR-amplified with the universal primer sets described by Weisburg et al. (1991) and Yamamoto \& Harayama (1995), respectively, and sequenced. The identity of a given PCR product was verified by bidirectional sequencing analysis. The phylogenetic relationships of the micro-organisms examined in this study were determined by comparing individual $16 \mathrm{~S}$ rRNA or gyrB gene sequences with sequences in the public databases using the BLAST algorithm (Altschul et al., 1990). The multiple alignment calculation of nucleotide substitution rates ( $K_{\text {nuc }}$ values), described by Kimura (1980), and the construction of phylogenetic trees by the neighbour-joining method (Saitou \& Nei, 1987) were performed using the CLUSTAL W computer program (Thompson et al., 1994). Alignment gaps, primer regions for PCR amplification and unidentified base positions were not taken into consideration in the calculations. The topological robustness of the phylogenetic trees was evaluated by a bootstrap analysis involving 1000 replications. The GenBank nucleotide accession numbers for the $16 \mathrm{~S}$ rRNA and gyrB gene sequences are shown in Table 1.

Table 2. Phenotypic differentiation between the novel isolates (B. safensis sp. nov.) and $B$. pumilus strains

Diagnostic traits were determined from a total of 174 biochemical tests. API tests (20NE, 20E, $50 \mathrm{CH}$, $50 \mathrm{CH}$ assimilation, $\mathrm{ZYM}$ ), tests of $\mathrm{NaCl}$ tolerance etc. were used to generate these results. Details of these tests are given in the text.

\begin{tabular}{|c|c|c|c|c|}
\hline \multirow[t]{2}{*}{ Reaction } & \multicolumn{2}{|c|}{ B. safensis sp. nov. } & \multicolumn{2}{|c|}{ B. pumilus } \\
\hline & FO- $36 b^{T}$ & $\begin{array}{c}\text { Twelve other } \\
\text { strains }^{\star}\end{array}$ & $\begin{array}{l}\text { ATCC } \\
7061^{T}\end{array}$ & $\begin{array}{c}\text { Five other } \\
\text { strains }^{\star}\end{array}$ \\
\hline \multicolumn{5}{|l|}{ Acid phosphatase } \\
\hline Lipase (Tween 80) & - & 17 & + & 100 \\
\hline Casein hydrolysis in litmus milk & - & 17 & + & 100 \\
\hline \multicolumn{5}{|l|}{ Acid production from: } \\
\hline Inositol & + & 100 & - & 0 \\
\hline Methyl $\alpha$-D-glucopyranoside & + & 100 & - & 80 \\
\hline Maltose & + & 100 & - & 80 \\
\hline D-Turanose & + & 100 & - & 80 \\
\hline \multicolumn{5}{|l|}{ Utilization of: } \\
\hline Inositol & + & 100 & - & 0 \\
\hline Methyl $\alpha$-D-glucopyranoside & + & 100 & - & 80 \\
\hline Melibiose & + & 100 & - & 80 \\
\hline Raffinose & + & 100 & - & 20 \\
\hline Maltose & + & 100 & - & 80 \\
\hline D-Turanose & + & 100 & - & 80 \\
\hline
\end{tabular}

${ }^{\star}$ Percentage of strains that gave a positive reaction. 


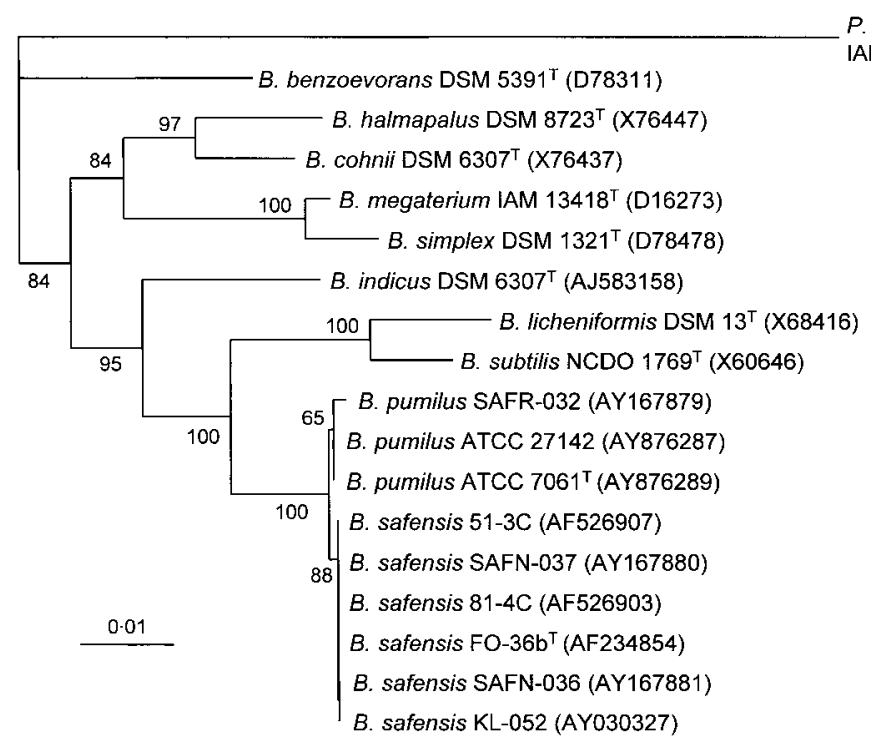

P. polymyxa

AM $13419^{\top}$ (D16276)
rep-PCRs were carried out according to the manufacturers' instructions (Bacterial Barcodes); the detailed protocol of the DiversiLab System LabChip kit used can be found elsewhere (http://www.bacbarcodes.com/diversilab/35-001800rev6\%20-LabChip.pdf). Analysis of PCR-fragment banding patterns and dendrogram construction were performed following the method of de Bruijn (1992). DNA-DNA hybridization was studied by using microplate hybridization methods (Ezaki et al., 1989) with photobiotin labelling and colorimetric detection, with 1,2-phenylenediamine (Sigma) as the substrate and a streptavidin-peroxidase conjugate (Boehringer Mannheim) as the colorimetric enzyme (Satomi et al., 1997).

Sequences of $1.4 \mathrm{~kb}$ of the $16 \mathrm{~S}$ rRNA genes (covering base positions 44-1471; Escherichia coli numbering) and the $1 \cdot 1 \mathrm{~kb}$ of the gyrB genes (covering base positions 316-1472; E. coli numbering) were used for phylogenetic analyses. The sequence similarity of $16 \mathrm{~S}$ rRNA genes among the novel
Fig. 1. Phylogenetic tree of members of the genus Bacillus, based on 16S rRNA gene sequences. The tree was constructed using the neighbour-joining method, and genetic distances were computed by using Kimura's model. Numbers at nodes indicate percentages of occurrence in 1000 bootstrapped trees. Paenibacillus polymyxa IAM $13419^{\top}$ was used as the outgroup. Accession numbers are given in parentheses. Bar, genetic distance of 0.01 . isolates was greater than $99.9 \%$. A phylogenetic tree based on the $16 \mathrm{~S}$ rRNA gene (Fig. 1) showed that the novel isolates clustered with members of the genus Bacillus, the nearest neighbour being B. pumilus ( $99 \cdot 9 \%$ sequence similarity). Since several reports have been published showing that strains with $>99 \% 16$ S rRNA gene sequence similarity may not belong to the same species (La Duc et al., 2004c; Satomi et al., 2002; Venkateswaran et al., 1999; Stackebrandt \& Goebel, 1994), comparative gyrB gene sequence analyses were carried out. As has been observed in previous studies (La Duc et al., 2004b) gyrB gene sequence-based phylogenetic topology proved more highly discriminative, grouping these strains monophyletically in a cluster separate from B. pumilus, clearly delineating them as a distinct species (Fig. 2). The sequence similarity values required to separate species on the basis of the gyrB gene vary according to the genus (Venkateswaran et al., 1999; Satomi et al., 2002, 2003, 2004). Additional reputable genetic analyses are therefore necessary to confirm the novelty of these isolates. On the

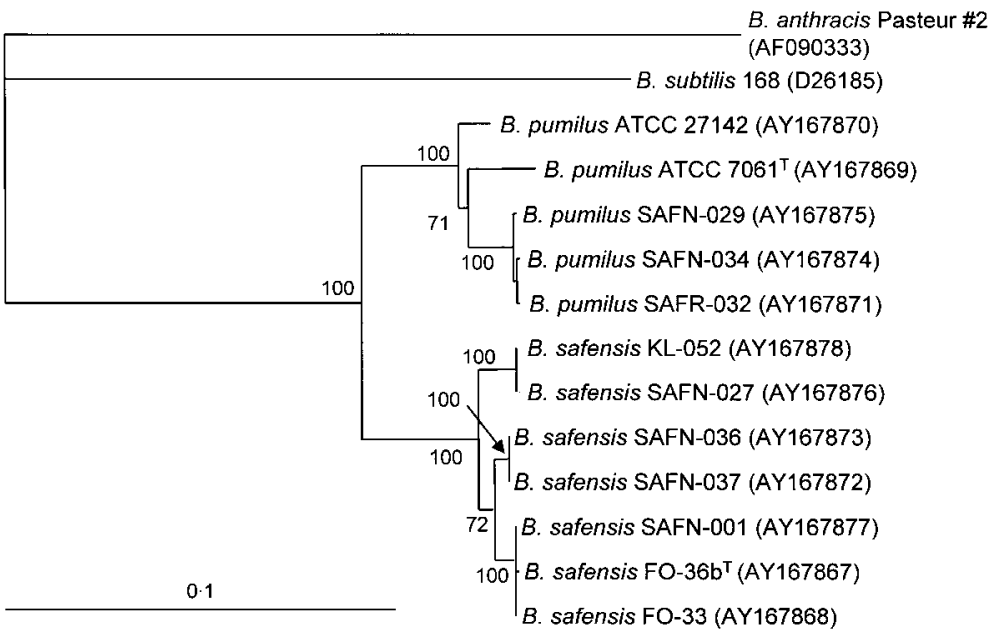

Fig. 2. Phylogenetic tree of the novel isolates and $B$. pumilus, based on gyrB gene sequences. The tree was constructed using the neighbour-joining method, and genetic distances were computed by using Kimura's model. Numbers at nodes indicate percentages of occurrence in 1000 bootstrapped trees. Bacillus anthracis Pasteur \#2 and Bacillus subtilis 168 served as the outgroup. Accession numbers are given in parentheses. Bar, genetic distance of $0 \cdot 1$. 
basis of the results of rep-PCR fingerprinting (Supplementary Fig. S1 available in IJSEM Online), all of the novel isolates are grouped together in their own cluster, separate from the distinct cluster formed by previously described $B$. pumilus strains, supporting the gyrB analysis and previous MALDI-TOF MS results (Dickinson et al., 2004). The most notable difference between the protein profiles of the $B$. pumilus type strain (ATCC $7061^{\mathrm{T}}$ ) and the proposed FO$36 \mathrm{~b}^{\mathrm{T}}$ strain group is the presence of a peak at $7620 \mathrm{Da}$, found only in the FO-36b ${ }^{\mathrm{T}}$ group strains (Dickinson et al., 2004). Another difference between the two groups is that the FO$36 \mathrm{~b}^{\mathrm{T}}$ group forms a tight cluster in terms of MALDI-TOF MS protein profiling. rep-PCR fingerprinting is able to resolve down to, and perhaps beyond, the species level. It has been used in recent taxonomic studies to evaluate DNA relatedness among bacterial strains (Thompson et al., 2003). The rep-PCR results generated in our work clearly distinguish the novel isolates from $B$. pumilus and, when coupled with supporting MALDI-TOF MS profiles (Dickinson et al., 2004), strongly suggest that these isolates should be recognized as belonging to a distinct genotype. To confirm the conclusions generated from the results of the phylogenetic analyses, DNA-DNA hybridization was performed (Supplementary Table S1 available in IJSEM Online). DNA-DNA hybridization revealed that the 13 novel isolates were all closely related (80-99\% DNA relatedness values), suggesting that they belong to the same species, but exhibited lower levels of hybridization with B. pumilus strains (54-66\%). This strongly supports the claim that these isolates represent a novel species within the genus Bacillus (Wayne et al., 1987).

The results from biochemical characterizations, $g y r B$ gene sequence analysis, DNA hybridization, rep-PCR profiling and MALDI-TOF MS protein profiling strongly indicated that the 13 novel strains isolated from spacecraft-assembly facilities represent a novel bacterial species within the genus Bacillus, although fatty acid methyl ester analysis and $16 \mathrm{~S}$ rRNA gene sequence analysis failed to discriminate between the tested isolates and B. pumilus. On the basis of the data from the polyphasic studies described above, the 13 isolates represent a novel species of the genus Bacillus, for which the name Bacillus safensis sp. nov. is proposed.

\section{Description of Bacillus safensis sp. nov.}

Bacillus safensis [sa.fen' sis. N.L. masc. adj. safensis arbitrarily derived from SAF (the spacecraft-assembly facility at the Jet Propulsion Laboratory, Pasadena, CA, USA), from where the organism was first isolated].

Cells are mesophilic, aerobic, chemoheterotrophic, Grampositive, spore-forming rods that are motile by means of polar flagella. Cells are $0 \cdot 5-0 \cdot 7 \mu \mathrm{m}$ in diameter and $1 \cdot 0$ $1 \cdot 2 \mu \mathrm{m}$ in length. Growth occurs at $0-10 \%(\mathrm{w} / \mathrm{v}) \mathrm{NaCl}$ and at pH $5 \cdot 6$. Growth occurs at $10-50{ }^{\circ} \mathrm{C}$ (optimum, $30-37^{\circ} \mathrm{C}$ ) but not at 4 or $55^{\circ} \mathrm{C}$. Colonies are round, undulate, dull white, non-luminescent and have irregular margins on TSA plates incubated at $32{ }^{\circ} \mathrm{C}$ for $24 \mathrm{~h}$. Oxidase, catalase, $\beta$-galactosidase, $\beta$-glucosidase, alkaline phosphatase, naphthol-AS-BI-phosphatase and esterase are produced, but $\mathrm{H}_{2} \mathrm{~S}$, indole, amylase, agarase, lecithinase, DNase, urease, leucine arylamidase, cystine arylamidase, valine arylamidase, trypsin, $\alpha$-galactosidase, $N$-acetyl- $\beta$-glucosamidase, $\alpha$-fucosidase, tryptophan deaminase, phenylalanine deaminase, arginine dihydrolase, lysine decarboxylase and ornithine decarboxylase are not. Cells do not reduce nitrate, but do hydrolyse gelatin, aesculin and RNA. Casein hydrolysis varies among strains. Voges-Proskauer test is positive. Growth occurs on agar plates supplemented with $1 \%$ glycine and ox gall, but does not occur in 0.0001 \% lysozyme broth. Negative for gas production from D-glucose. Acid is produced from D-glucose, glycerol, L-arabinose, ribose, D-xylose, galactose, fructose, mannose, inositol, mannitol, methyl $\alpha$-D-mannopyranoside, methyl $\alpha$-D-glucopyranoside, $\mathrm{N}$-acetylglucosamine, amygdalin, arbutin, salicin, cellobiose, maltose, sucrose, trehalose, D-turanose and D-tagatose, but not from erythritol, D-arabinose, L-xylose, adonitol, methyl $\beta$-D-xylopyranoside, sorbose, rhamnose, dulcitol, sorbitol, inulin, melezitose, raffinose, starch, glycogen, xylitol, Dlyxose, D-fucose, L-fucose, D-arabitol, L-arabitol, gluconate, 2-ketogluconate or 5-ketogluconate. Reactions for lactose, melibiose and gentiobiose vary among strains. Citrate, malate, D-glucose, glycerol, L-arabinose, ribose, D-xylose, galactose, fructose, mannose, inositol, mannitol, methyl $\alpha$-D-mannopyranoside, methyl $\alpha$-D-glucopyranoside, $N$ acetylglucosamine, amygdalin, arbutin, salicin, cellobiose, maltose, sucrose, trehalose, gentiobiose, D-turanose, D-tagatose, gluconate, lactate, L-aspartate and L-glutamate are readily utilized as energy sources. Erythritol, D-arabinose, L-xylose, adonitol, methyl $\beta$-D-xylopyranoside, sorbose, dulcitol, sorbitol, inulin, lactose, melezitose, starch, glycogen, xylitol, D-lyxose, D-fucose, L-fucose, D-arabitol, L-arabitol, 2-ketogluconate, 5-ketogluconate, capric acid, adipic acid, phenylacetic acid, propionate and glycine are not utilized as energy sources. Rhamnose utilization varies among strains. The DNA G + C content is $41 \cdot 0-41 \cdot 4 \mathrm{~mol} \%$. The chain composition of the whole-cell fatty acids is primarily $\mathrm{C}_{15: 0}$ iso, $\mathrm{C}_{15: 0}$ anteiso, $\mathrm{C}_{17: 0}$ iso and $\mathrm{C}_{17: 0}$ anteiso.

The type strain, FO- $36 \mathrm{~b}^{\mathrm{T}}$ (=ATCC BAA- $1126^{\mathrm{T}}=\mathrm{NBRC}$ $100820^{\mathrm{T}}$ ), was isolated from the spacecraft-assembly facility of the Jet Propulsion Laboratory, Pasadena, CA, USA. Strains SAFN-001 (=ATCC BAA-1128=NBRC 100821), KL-052 (=ATCC BAA-1129= NBRC 100822) and 51-3C $(=$ ATCC BAA-1127 $=$ NBRC 100823 $)$ are reference strains.

\section{Acknowledgements}

The research described in this publication was carried out at the Jet Propulsion Laboratory, California Institute of Technology, under a contract with the National Aeronautics and Space Administration. We thank all of the members of the Biotechnology and Planetary Protection Group (Jet Propulsion Laboratory) for sampling, analysis and discussion. We thank C. Echeverria, R. Sumner and A. Baker for technical help and H. Oikawa for performing $\mathrm{G}+\mathrm{C}$ content analyses. 
We also thank A. Thrasher, M. Ott and D. Pierson (Johnson Space Center) for performing the rep-PCR analysis and supplying B. pumilus 0105342-2 isolated from International Space Station hardware.

\section{References}

Altschul, S. A., Gish, W., Miller, W., Myers, E. W. \& Lipman, D. J. (1990). Basic local alignment search tool. J Mol Biol 215, 403-410. Anonymous (1980). NASA standard procedures for the microbiological examination of space hardware, NHB5340.1B. Pasadena, CA: National Aeronautics and Space Administration.

Claus, D. \& Berkeley, R. C. W. (1986). Genus Bacillus Cohn 1872. In Bergey's Manual of Systematic Bacteriology, vol. 2, pp. 1105-1139. Edited by P. H. A. Sneath, N. S. Mair, M. E. Sharpe \& J. G. Holt. Baltimore: Williams \& Wilkins.

de Bruijn, F. J. (1992). Use of repetitive (repetitive extragenic palindromic and enterobacterial repetitive intergeneric consensus) sequences and the polymerase chain reaction to fingerprint the genomes of Rhizobium meliloti isolates and other soil bacteria. Appl Environ Microbiol 58, 2180-2187.

Dickinson, D. N., La Duc, M. T., Satomi, M., Wineforder, J. D., Powell, D. H. \& Venkateswaran, K. (2004). MALDI-TOF MS compared with other polyphasic taxonomy approaches for the identification and classification of Bacillus pumilus spores. J Microbiol Methods 58, 1-12.

Ezaki, T., Hashimoto, Y. \& Yabuuchi, E. (1989). Fluorometric deoxyribonucleic acid-deoxyribonucleic acid hybridization in microdilution wells as an alternative to membrane filter hybridization in which radioisotopes are used to determine genetic relatedness among bacterial strains. Int J Syst Bacteriol 39, 224-229.

Johnson, J. L. (1981). Genetic characterization. In Manual of Methods for General Bacteriology, pp. 450-472. Edited by P. Gerhardt, R. G. E. Murray, R. N. Costilow, E. W. Nester, W. A. Wood, N. R. Krieg \& G. B. Phillips. Washington, DC: American Society for Microbiology.

Kempf, M. J., Cheng, F., Kern, R. \& Venkateswaran, K. (2005). Recurrent isolation of hydrogen peroxide-resistant spores of Bacillus pumilus from a spacecraft assembly facility. Astrobiology 5, 391-405.

Kimura, M. (1980). A simple method for estimating evolutionary rates of base substitutions through comparative studies of nucleotide sequences. J Mol Evol 16, 111-120.

La Duc, M. T., Nicholson, W., Kern, R. \& Venkateswaran, K. (2003). Microbial characterization of the Mars Odyssey spacecraft and its encapsulation facility. Environ Microbiol 5, 977-985.

La Duc, M. T., Kern, R. \& Venkateswaran, K. (2004a). Microbial monitoring of spacecraft and associated environments. Microb Ecol 47, 150-158.

La Duc, M. T., Satomi, M. \& Venkateswaran, K. (2004b). Bacillus odysseyi sp. nov., a round-spore-forming bacillus isolated from the Mars Odyssey spacecraft. Int J Syst Evol Microbiol 54, 195-201.

La Duc, M. T., Satomi, M., Agata, N. \& Venkateswaran, K. (2004c). gyrB as a phylogenetic discriminator for members of the Bacillus anthracis-cereus-thuringiensis group. J Microbiol Methods 56, 383-394.

Nicholson, W. L. \& Setlow, P. (1990). Sporulation, germination, and outgrowth. In Molecular Biological Methods for Bacillus, pp. 391-450. Edited by C. R. Harwood \& S. M. Cutting. Chichester: Wiley.

Puleo, J. R., Fields, N. D., Bergstrom, S. L., Oxborrow, G. S., Stabekis, P. D. \& Koukol, R. (1977). Microbiological profiles of the Viking spacecraft. Appl Environ Microbiol 33, 379-384.

Saitou, N. \& Nei, M. (1987). The neighbor-joining method: a new method for reconstructing phylogenetic trees. Mol Biol Evol 4, 406-425.
Sambrook, J., Fritch, E. F. \& Maniatis, T. (1989). Molecular Cloning: a Laboratory Manual, 2nd edn. Cold Spring Harbor, NY: Cold Spring Harbor Laboratory.

Sasser, M. (1990). Identification of bacteria by gas chromatography of cellular fatty acids. Technical Note 101. Newark, DE: MIDI, Inc.

Satomi, M., Kimura, B., Mizoi, M., Satou, T. \& Fujii, T. (1997). Tetragenococcus muriaticus sp. nov., a new moderately halophilic lactic acid bacterium isolated from fermented squid liver sauce. Int J Syst Bacteriol 47, 832-836.

Satomi, M., Kimura, B., Hamada, T., Harayama, S. \& Fujii, T. (2002). Phylogenetic study of the genus Oceanospirillum based on 16S rRNA and gyrB genes: emended description of the genus Oceanospirillum, description of Pseudospirillum gen. nov., Oceanobacter gen. nov. and Terasakiella gen. nov. and transfer of Oceanospirillum jannaschii and Pseudomonas stanieri to Marinobacterium as Marinobacterium jannaschii comb. nov. and Marinobacterium stanieri comb. nov. Int J Syst Evol Microbiol 52, 739-747.

Satomi, M., Oikawa, H. \& Yano, Y. (2003). Shewanella marinintestina sp. nov., Shewanella schlegeliana sp. nov. and Shewanella sairae sp. nov., novel eicosapentaenoic-acid-producing marine bacteria isolated from sea-animal intestines. Int J Syst Evol Microbiol 53, 491-499.

Satomi, M., Kimura, B., Hayashi, M., Okuzumi, M. \& Fujii, T. (2004). Marinospirillum insulare sp. nov., a novel halophilic helical bacterium isolated from kusaya gravy. Int J Syst Evol Microbiol 54, 163-167.

Schaeffer, P., Millet, J. \& Aubert, J.-P. (1965). Catabolic repression of bacterial sporulation. Proc Natl Acad Sci U S A 54, 704-711.

Smibert, R. M. \& Krieg, N. R. (1994). Phenotypic characterization. In Methods for General and Molecular Bacteriology, pp. 607-654. Edited by P. Gerhardt, R. G. E. Murray, W. A. Wood, \& N. R. Krieg. Washington, DC: American Society for Microbiology.

Stackebrandt, E. \& Goebel, B. M. (1994). Taxonomic note: a place for DNA-DNA reassociation and 16S rRNA sequence analysis in the present species definition in bacteriology. Int J Syst Bacteriol 44, 846-849.

Tamaoka, J. \& Komagata, K. (1984). Determination of DNA base composition by reversed-phase high performance liquid chromatography. FEMS Microbiol Lett 25, 125-128.

Thompson, J. D., Higgins, D. G. \& Gibson, T. J. (1994). CLUSTAL W: improving the sensitivity of progressive multiple sequence alignment through sequence weighting, position-specific gap penalties and weight matrix choice. Nucleic Acids Res 22, 4673-4680.

Thompson, F. L., Thompson, C. C., Li, Y., Gomez-Gil, B., Vandenberghe, J., Hoste, B. \& Swings, J. (2003). Vibrio kanaloae sp. nov., Vibrio pomeroyi sp. nov. and Vibrio chagasii sp. nov., from sea water and marine animals. Int J Syst Evol Microbiol 53, 753-759.

Venkateswaran, K., Moser, D. P., Dollhopf, M. E. \& 10 other authors (1999). Polyphasic taxonomy of the genus Shewanella and description of Shewanella oneidensis sp. nov. Int J Syst Bacteriol 49, 705-724.

Venkateswaran, K., Satomi, M., Chung, S., Kern, R., Koukol, R., Basic, C. \& White, D. (2001). Molecular microbial diversity of a spacecraft assembly facility. Syst Appl Microbiol 24, 311-320.

Wayne, L. G., Brenner, D. J., Colwell, R. R. \& 9 other authors (1987). Report of the ad hoc committee on reconciliation of approaches to bacterial systematics. Int J Syst Bacteriol 37, 463-464.

Weisburg, W. G., Barns, S. M., Pelletier, D. A. \& Lane, D. J. (1991). $16 \mathrm{~S}$ ribosomal DNA amplification for phylogenetic study. J Bacteriol 173, 697-703.

Yamamoto, S. \& Harayama, S. (1995). PCR amplification and direct sequencing of $g y r B$ genes with universal primers and their application to the detection and taxonomic analysis of Pseudomonas putida strains. Appl Environ Microbiol 61, 1104-1109. 